\title{
Nowa Huta, Krakow, Poland: Old urbanism, New urbanism?
}

\author{
Anna Agata Kantarek ${ }^{1}$, Ivor Samuels ${ }^{2}$ \\ ${ }^{1}$ Faculty of Architecture, Kraków University of Technology, Kraków, Poland \\ ${ }^{2}$ Urban Morphology Research Group, School of Geography, University of Birmingham, Oxford, \\ UK \\ E-mail: 1akanta@poczta.onet.pl, ${ }^{2}$ ivor.samuels@googlemail.com
}

\begin{abstract}
This paper considers the first stage of Nowa Huta New Town built near Krakow in the 1950s. In contrast to UK and US new settlements of the post war period it is a high density apartment block development which was ignored in the literature for more than half a century because its design, apparently based on a system of streets, is in contrast with contemporary forms of development, either low density garden city or higher density free standing apartment blocks. A discussion of its neglect and the recent rediscovery of its qualities, both in Poland and by exponents of the US New Urbanism (part of the Urban Morphology spectrum somewhat neglected by ISUF) leads to a systematic investigation of the development, its influences and how this project conceived in a radically different political and economic context, matches or departs from the tenets of the Charter for the New Urbanism. The extent to which the context has determined the differences leads to a conclusion discussing the enduring qualities and contemporary relevance of inherited urban forms.
\end{abstract}

Keywords: Poland; Nowa Huta, Krakow, New Urbanism, Socrealism, housing, streets

\section{Introduction}

In a conference held in Krakow Elizabeth Plater Zyberk, doyenne of the New Urbanism movement in the US, concluded her address by declaring that "... you have excellent examples of modern town building here in Poland. I was happy to hear that Nowa Huta is being rehabilitated in the literature. It is a remarkable achievement with a highly characteristic sense of place, connected to the city of Krakow by transit, and exhibiting so many of the principles of good urbanism. So you have beautiful models, in your more distant history but also in a more recent history of planning." (Plater Zyberk 2015).

Until recently this new town was ignored in English literature. For example abook published in English to celebrate the achievement of modern Polish architecture ignores the earlier neighbourhood of the new town, those admired by Plater Zyberk, and only includes later tower blocks characteristic of so many Post World War Two housing developments throughout the world (Lisowski 1968).

While there has been a renewed interest in the architecture of the Stalinist hegemony in Eastern Europe (Hatherley, 2015) this has been primarily focussed on the social and political aspects (Lebow, 2013, Stenning, 2000) or the broader planning issues of the post socialist states in general (Hirst and Stanilow 2009).

Following a brief description of the earlier stages of the project and an exploration of the cultural reasons for its neglect (including the changing fashions of architects) Nowa Huta is examined with respect to the extent to which it fulfils the tenets set out in the Charter of the New Urbanism (1999).

Nowa Huta, a Polish New Town, was designed and built in the 1950s. For those 
coming from an anglophone context it is of particular interest because, in contrast to UK and US new settlements of the post war period it is a high density apartment block development. From an urban form point of view its design around a system of streets is in contrast with the prevailing forms of development either low density garden city (e.g. The UK New Towns ) or higher density free standing apartment blocks (e.g. Muratori 's Rome housing at Tuscolano 1949 -50, Maretto 2012 ).

Although New Urbanism clearly fits into the canon of urban morphology (Gautier and Gilliland 2006) it has been relatively neglected in the literature of urban morphology in spite of its impact on the practice of urban design e.g. in the US, Seaside and in the UK, Poundbury. It is therefore considered appropriate to discuss the morphology of Nowa Huta to the extent to which it converges with the principles of this movement.

Given its neglect in the literature so that many urban designers outside Poland would not be acquainted with Nowa Huta this paper starts by describing briefly the first stages of its development which are the focus of this study. It then sets out the main tenets of New Urbanism and then compares these with the realisation of Nowa Huta. Since the topic is too extensive for a single paper we will focus on one canon of NU, that of walkability. This will facilitate a discussion of aspects of the street layout, its connectivity and the relation between the private space of the dwellings and the public space system, which are arguably the most distinguishing characteristics of the composition and structure of Nowa Huta.

\section{Urban history of Nowa Huta}

The new town is located east of the old city and now forms part of metropolitan Krakow. It was built by the communists on fertile agricultural land for the house workers of an enormous steel mill (Nowa Huta means New Steel Mill). Building started in 1949 and the sector this paper focuses on, Old Nowa Huta, was completed in 1955 (Komorowski, 2005). Construction continued after that date but with a more modernist typology with separate blocks set in landscaped communal areas.

The authors of the plan, with Tadeusz Ptaszycki as a leader (Juchnowicz, 2005), (Ptaszycki, 1953), (Bittner, 1971), did not have much design practice experience and based the concept on the knowledge acquired during their studies, although it is considered that Magnitogorsk could be a model.

The undeveloped area allowed the perfect realization of the selected composition. A geometric layout of streets radially spreading from the central square was the basis of the scheme. This square is placed on the edge of the Vistula slope where it reaches over $14 \mathrm{~m}$ in height. The square opened to the south with a wide panoramic view and a panorama of the

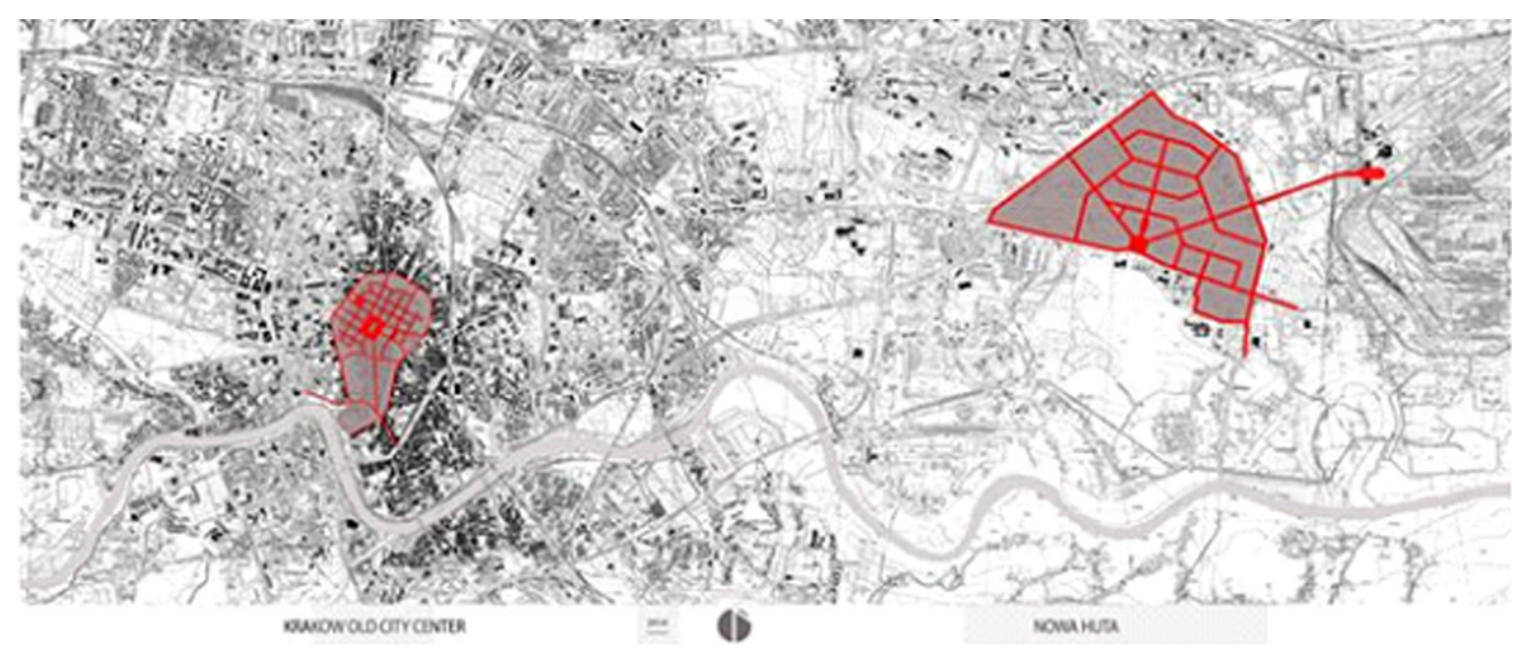

Figure 1. Nowa Huta location in Krakow (A. A. Kantarek on (IX International Biennale of Architecture, 2002) 
Tatra Mountains on clear days. It is the main point and dominant feature of the composition with streets connecting the district (once a separate town ) from the center of Krakow (on the west) and the Steel Mill (from the north east) (Juchnowicz, 1986), (Miezian at al, 2006), (Lorek, 1999), (Smaga, 2017).

a - General view of the urban model designed by T. Ptaszycki with the team, 1950-1051 (publ. Architektura Polska 1950-1951, Institute of Urban Design and ArchitecturePWT Warszawa, 1953;

b - Nowa Huta, the design of the green areas with the concept of the South Park - by S. Juchnowicz and the team, 1954;

c - A model of the Nowa Huta Centre, a southern view, designed by T. Ptaszycki with the team, 1950-1051 (publ. Architektura Polska 1950-1951, Institute of Urban Design and Architecture PWT Warszawa, 1953

Large blocks of buildings surrounding the square were designed according to the rules

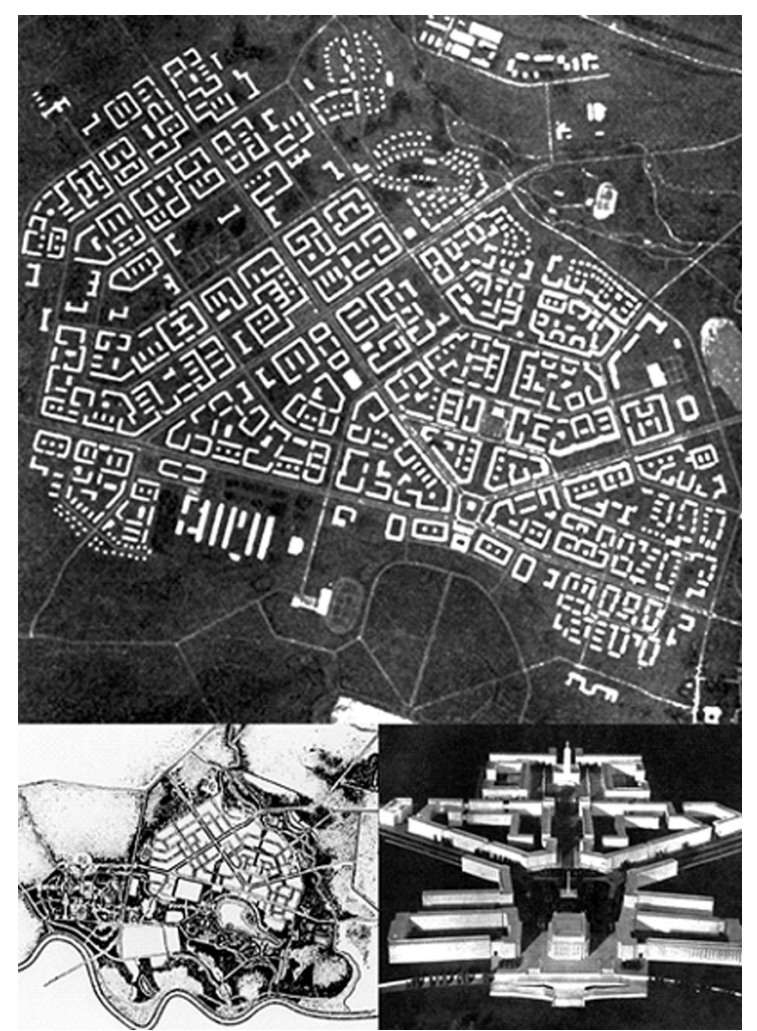

Figure 2. Nowa Huta urban structure as designed (IX International Biennale of Architecture, 2002)

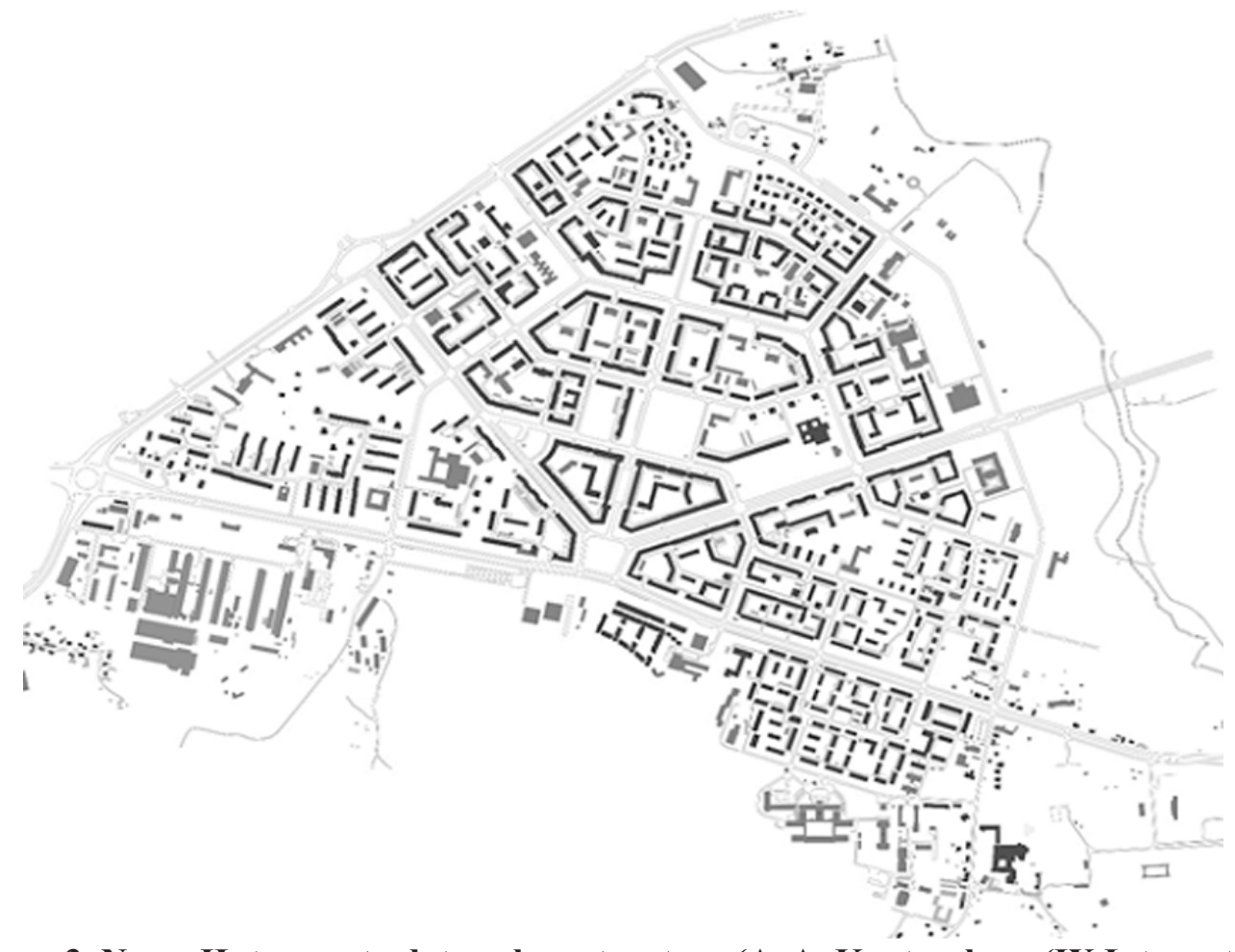

Figure 3. Nowa Huta - up to date urban structure (A. A. Kantarek on (IX International Biennale of Architecture, 2002) 
of neighbourhood units with 5,000 to 6,000 residents and the basic facilities needed: crèches, kindergartens, schools together with the necessary commercial, crafts, gastronomic and cultural services .

Shops are located within the deep of residential blocks and these are now proving a problem for larger shop units although some blocks of specially designed retail units of a greater depth have been built. All the homes are in apartment buildings with four to seven storeys with staircase access and elevators.

To quote a recent observation by $\mathrm{S}$. Juchnowicz, a member of the original project team (Urbaniec, 2014): "From today's perspective, Nowa Huta is a global phenomenon (...) It represents the value, also cultural, of this urban composition. The project of Nowa Huta is done with authenticity, it is a compact concept, based on regular streets and squares, referring to the historical heritage."

Nowa Huta was built on expropriated private land - another important factor that gives us an idea of those times. Plunder rather than expropriation meant taking ownership of the property and symbolic payment was made only in order to document ownership.

It is worth mentioning that Nowa Huta's structure was inscribed in 2004 by the Malopolska Voivodship Monuments Conservator into the Register of Historic Monuments (Decyzja, 2004). The Act decided to: "Enter in the Register of Historic Monuments of the City of Cracow under registration number A-1132 the following cultural asset: The Urban layout of Nowa Huta district in Cracow, as a representative example of the urbanism of socialist realism in Poland. The subject of the protection is the urban layout, i.e. the layout of streets, squares, green areas, location of blocks and dimensions of the buildings, architectural and landscape enclosures, composition of greenery (...)".

While some attention has been given in the Anglophone literature to Stalinist architecture, much less attention has been paid in general to its Polish versions and in particular to Nowa Huta. Nevertheless its development broadly fits into the time scale of the embrace of modernism and its subsequent rejection in urban development. However this process worked out in a syncopated way on either side of the Iron Curtain. A common way of denigrating Modern Movement architecture is to associate it with the architecture of Soviet Communism. Thus the blocks of such notorious developments as Ronan Point and Pruitt Igoe have been labelled as Soviet because 'they are repetitious and use reinforced concrete' (Hatherley, 2015. p5). But it is necessary to point out that many of these developments were openly following the models of contemporary western architects such as Le Corbusier, especially in their rejection of the corridor street and its replacement by free standing blocks in landscaped parkland.

In fact, after some years of modernism after the Russian Revolution, from the 1930s to the mid 1950s (a date which coincides with the building of Nowa Huta ) it was rejected as coming from the West. The intention was to show in architecture and urbanism a dependence on a style derived from the USSR while at the same time arguing that it was a national style of building. Modernism was to be rejected decades later in the West by the post modernists of the 1970s and the 1980s as being repetitious and inhuman (Hatherley, 2015) in favour of urban forms which referred to local traditions and in particular to the importance of the street and the urban block (Panerai et al, 2004).

Thus local critics writing in the 1960s at the zenith of modernism would praise the second stage of Nowa Huta with its tower blocks standing in parkland and ignore the first stage. (Lisowski (1968). Only recently following the rediscovery of the street by the New Urbanists, among others, has its virtues begun to be recognised (Plater Zyberk, 2015).

\section{New Urbanism principles realized in Nowa Huta?}

In order to consider to what extent this new town follows the tenets of New Urbanism reference is made to those that are relevant to a new town or a district of a metropolitan area and to housing in detail as set out in three sections of the Charter. It is not considered that the regional scale which is the topic of the first section of the Charter is appropriate to Nowa Huta. 
Walkability - street and urban block

Table 1. Brief Summary of Nowa Huta assessed against Principles of New Urbanism

\begin{tabular}{|l|l|l|}
\hline $\begin{array}{l}\text { New Urbanism } \\
\text { http://www.newurbanism.org/n } \\
\text { ewurbanism/principles.html }\end{array}$ & Nowa Huta as designed and built & Nowa Huta today \\
\hline 1. Walkability & $\begin{array}{l}\text { Yes, wide sidewalks along large scale } \\
\text { monumental streets; but unfriendly } \\
\text { interface between dwellings and } \\
\text { streets; entrances at back of blocks; } \\
\text { initially car ownership limited. }\end{array}$ & $\begin{array}{l}\text { Yes and no. Increased car use with high } \\
\text { speeds on wide straight roads; car } \\
\text { parking problems; some main routes } \\
\text { blocked by central barriers to speed } \\
\text { trams }\end{array}$ \\
\hline 2. Connectivity & $\begin{array}{l}\text { Yes. based on hierarchy of movement } \\
\text { networks; interconnected street grid } \\
\text { easy for walking and inner superblock } \\
\text { space well connected and accessible; } \\
\text { low } \\
\text { quality of services and design of } \\
\text { pedestrian spaces. }\end{array}$ & $\begin{array}{l}\text { Yes, with no major changes compared } \\
\text { to the initial design }\end{array}$ \\
\hline $\begin{array}{l}\text { 3. Mixed-Use \& } \\
\text { Diversity }\end{array}$ & $\begin{array}{l}\text { No. Main workplace separate from } \\
\text { town; limited services; socially } \\
\text { homogeneous. }\end{array}$ & $\begin{array}{l}\text { Improved with increase in the number } \\
\text { of services inserted existing fabric; } \\
\text { more social diversity; }\end{array}$ \\
\hline
\end{tabular}

\begin{tabular}{|c|c|c|}
\hline 4. Mixed Housing & No, only multi-family housing & $\begin{array}{l}\text { Gradual improving standard of flats and } \\
\text { buildings; combination of small } \\
\text { multifamily units into larger homes }\end{array}$ \\
\hline $\begin{array}{l}\text { 5. Quality Architecture } \\
\text { \& Urban Design }\end{array}$ & $\begin{array}{l}\text { Yes, with emphasis on political role of } \\
\text { architecture as it was the prestigious } \\
\text { new town built after WW Il }\end{array}$ & $\begin{array}{l}\text { The neglected socialist realist } \\
\text { architecture has been slowly } \\
\text { refurbished and appreciated as witness } \\
\text { of an epoch and part of national } \\
\text { heritage. }\end{array}$ \\
\hline $\begin{array}{l}\text { 6. Traditional } \\
\text { Neighbourhood } \\
\text { Structure }\end{array}$ & $\begin{array}{l}\text { Yes, functional programme was based } \\
\text { on Neighbourhood Unit and form built } \\
\text { on positive urban space. } \\
\text { Some elements unrealised because of } \\
\text { financial problems (sport, greenery). }\end{array}$ & $\begin{array}{l}\text { Yes, with additional elements of } \\
\text { functional program. }\end{array}$ \\
\hline 7. Increased Density & $\begin{array}{l}\text { Yes, it was a town with relatively high } \\
\text { density although less than in the City } \\
\text { Centre of Krakow. It was planned for } \\
100000 \text { inhabitants. }\end{array}$ & $\begin{array}{l}\text { During } 50 \text { years there were some } \\
\text { elements of the programme } \\
\text { incorporated (scheols and its } \\
\text { expansion); some modernization of roof } \\
\text { space in multifamily housing } \\
\text { Nowa Huta District is } 65,41 \mathrm{~km}^{2} \text { with } \\
54588 \text { inhabitants and with density } \\
835 \text { persons } / \mathrm{km}^{2}\end{array}$ \\
\hline $\begin{array}{l}\text { 8. Green } \\
\text { Transportation }\end{array}$ & $\begin{array}{l}\text { Mass transport based on - bus, tram and } \\
\text { cycles; } \\
\text { cycle network implemented }\end{array}$ & $\begin{array}{l}\text { Mass transport still effective because of } \\
\text { car congestion and parking problems; } \\
\text { cycle routes converted to car parking; } \\
\text { cycles use pedestrian routes or car } \\
\text { streets. }\end{array}$ \\
\hline 9. Sustainability & $\begin{array}{l}\text { Doubtful sustainability since town } \\
\text { located on good agricultural land; } \\
\text { traditional building technologies } \\
\text { respected environment; } \\
\text { development carefully located in } \\
\text { relation to River Vistula scarp with } \\
\text { open views to south }\end{array}$ & $\begin{array}{l}\text { A large number of buildings have been } \\
\text { modemized (insulation, new windows); } \\
\text { planted areas neglected but vegetation } \\
\text { has matured }\end{array}$ \\
\hline 10. Quality of Life & Yes, as politically declared. & $\begin{array}{l}\text { For years considered as a subordinate, } \\
\text { working-class district, now gradually } \\
\text { recognized as attractive, full of } \\
\text { greenery and life-friendly environment. }\end{array}$ \\
\hline
\end{tabular}


It has been noted that almost all the entrances to the staircases and lifts are located towards the internal common space i.e. on the back of the buildings with respect to the street facades. With a few exceptions, there are no entrances on the street side, the front. This reinforces the inhabitants' identity with the urban block rather than the street. This is strengthened by postal addresses being given by urban block number rather than street address. Thus although the streets are such an important element of the plan it is doubtful whether they can be considered as comparable with those of a traditional layout where the entrances to

OSIEDLE CENTRUM C

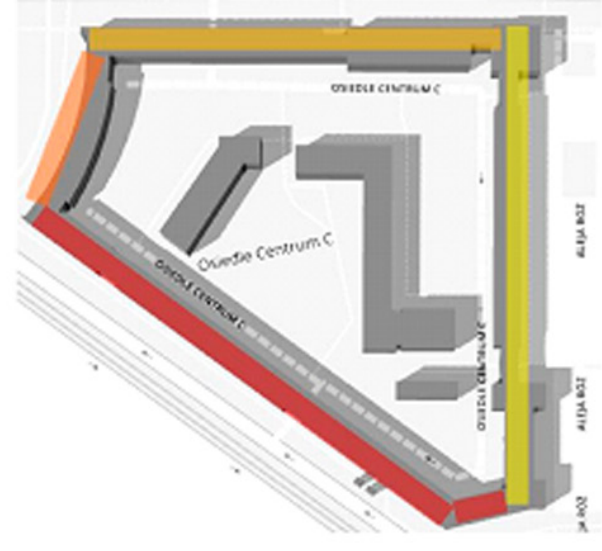

the dwellings act as the interface between the public and private realms. This must certainly reduce considerably the extent to which Nowa Huta can be considered as responding to the tenets of New Urbanism.

The configuration of the main streets, wide and straight with no traffic calming measures, encourages high vehicle speeds while some of the main streets have long central barriers which enable the trams to travel at high speed but hinder connectivity for pedestrians between the urban blocks.

One of the four urban blocks of Nowa Huta (Osiedle Centrum C) situated in its center
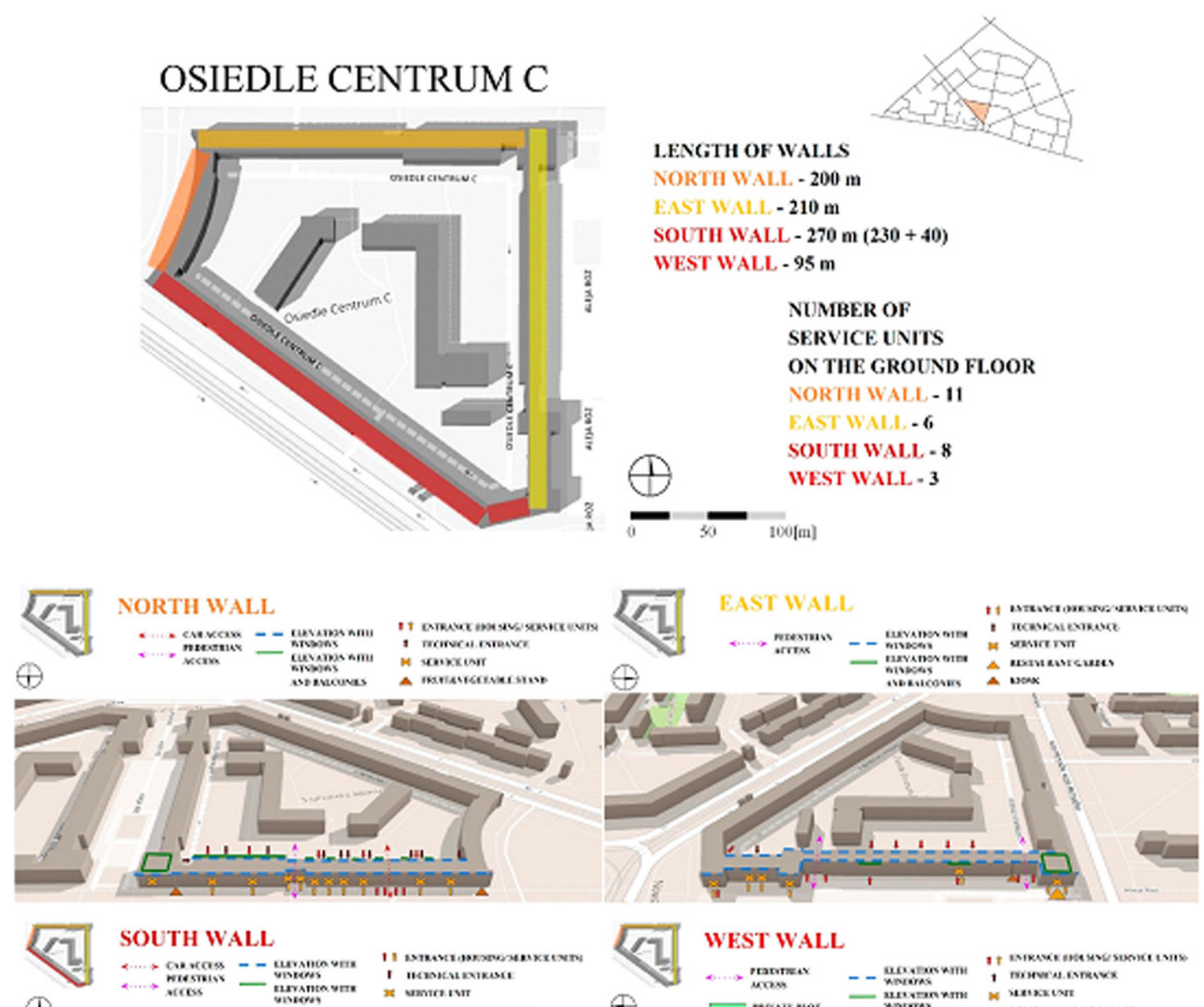

SOUTH WALL

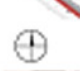

$2 \ldots \rightarrow$ misesive

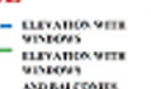

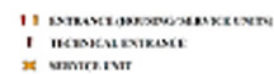

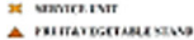

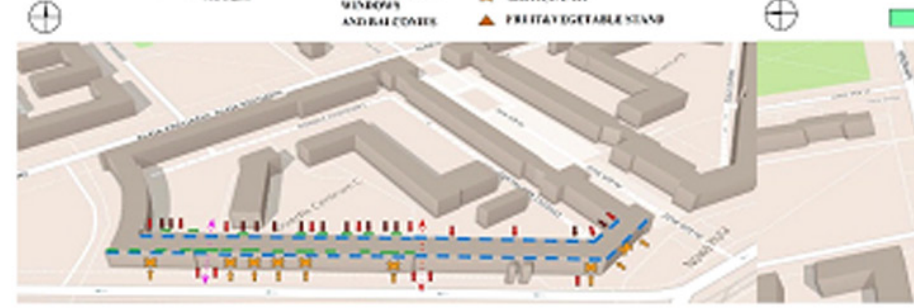

WEST WALL

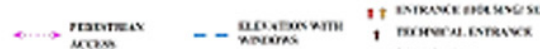

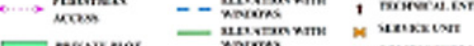

D rovsenot -

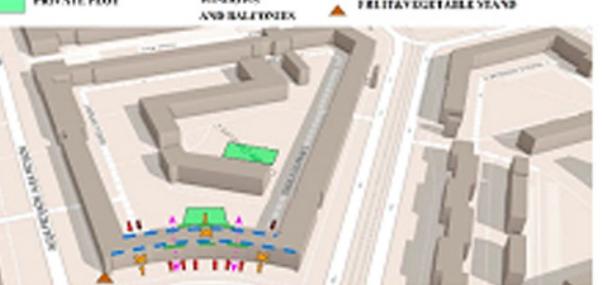

Figure 4. Osiedle Centrum C - walkability (A. Lis, A. Maliga, A. A. Kantarek) 
is presented below. Its south facade forms the part of the main square of the district (R. Reagan Square). The following public spaces are defined by it (some of the names have been continuously changed since 1991):

-Plac R. Reagana (R. Reagan Square),

-Aleja Generała Władysława Andersa (Gen.

W. Anders Avenue) - with tram line,

-Service street (no name),

-Aleja Przyjaźni (Avenue of Friendship),

-Aleja Róż (Avenue of Roses) pedestrian zone

At the same time car movement takes place not only along the external roads but also through service roads within the urban block. With a very small number of parking spaces it is noteworthy that the urban block has car movement supported on both sides of the buildings defining its shape, overwhelmingly ( $82 \%$ of the outer perimeter and $90 \%$ internal). The pedestrian pavements along the outer streets and on the façades of the buildings are spacious. This allows the incorporation of a variety of functions. However, despite these advantages the services in the ground floor and with windows in the facades, overlooking the pavement, are poorly managed. Only a few services offer activities outside, there are no benches or any provision of green spaces (playgrounds, resting places, etc.)

Table 2. shows some parameters of Osiedle Centrum $\mathrm{C}$ pedestrian zone. Quite a large part of ground floor is used for different commercial functions and there is a wide pedestrian pavement.

Table 3. and 4. present Osiedle Centrum $\mathrm{C}$ characteristics related to the quality of the urban frontages with the number of entrances and windows which give perspective of the role of the building in activating the public space. This study was carried out to ascertain the extent to which it meets the rules of good frontages according to the Gehl scale (Gehl, 1994).

\section{Commentary}

Table 2. Osiedle Centrum C pedestrian zone

\begin{tabular}{|l|c|c|c|}
\hline $\begin{array}{l}\text { Osiedle Centrum C } \\
\text { pedestrian zone }\end{array}$ & Width (m) & $\begin{array}{c}\text { Pedestrian zone to the } \\
\text { frontage of Osiedle } \\
\text { Centrum C (m) }\end{array}$ & $\begin{array}{c}\text { Lawn on the side of } \\
\text { Osiedle Centrum C } \\
\text { (m) }\end{array}$ \\
\hline R. Reagan Square & $\begin{array}{c}96 \text { (to the center of the } \\
\text { square) }\end{array}$ & 12 & 15 max \\
\hline Gen. W. Anders Avenue & $49-58$ & 6,4 & 5,4 \\
\hline Service street & $\begin{array}{c}22 \text { (to the greenery on an } \\
\text { another side of the street) }\end{array}$ & 16 & $\begin{array}{c}\text { only 9 m lawn on } 18 \% \text { of } \\
\text { the frontage length }\end{array}$ \\
\hline Avenue of Friendship & $47-50$ & 5 & 8 \\
\hline Avenue of Roses & 52 & 52 & $\begin{array}{c}\text { (only row of trees in } \\
\text { pedestrian zone) }\end{array}$ \\
\hline
\end{tabular}

Table 3. Osiedle Centrum C - characteristics of facades

\begin{tabular}{|l|c|c|c|c|}
\hline Osiedle Centrum C urban block & North wall & East wall & South wall & West wall \\
\hline Length $(\mathrm{m})$ & 200 & 210 & 270 & 95 \\
\hline Service units & 11 & 6 & 8 & 3 \\
\hline Premises/100m & 6 & 3 & 3 & 3 \\
\hline $\begin{array}{l}\text { Entrances } \\
\text { Housing/service units/inner block space }\end{array}$ & $4 / 10 / 2$ & $7 / 7 / 2$ & $5 / 9 / 2$ & $6 / 2 / 2$ \\
\hline$\Sigma$ entrances & 16 & 16 & 16 & 10 \\
\hline Entrances/100m & 8 & 8 & 6 & 11 \\
\hline Windows & 40 & 33 & 51 & 19 \\
\hline Entrances+windows/100m & 28 & 18 & 25 & 31 \\
\hline $\begin{array}{l}\text { Entrances on inner wall - housing/service } \\
\text { units/technical/to the street }\end{array}$ & $5 / 0 / 8 / 2$ & $6 / 0 / 1 / 2$ & $10 / 0 / 13 / 2$ & $1 / 1 / 2 / 2$ \\
\hline
\end{tabular}


Table 4. Osiedle Centrum C urban block - a quality of frontages (Gehl, 1994:33, 34)

\begin{tabular}{|l|c|c|c|c|}
\hline Osiedle Centrum C urban block & North wall & East wall & South wall & West wall \\
\hline Service units every 100m & $\begin{array}{c}\mathrm{C} \\
(6)\end{array}$ & $\begin{array}{c}\mathrm{D} \\
(3)\end{array}$ & $\begin{array}{c}\mathrm{D} \\
(3)\end{array}$ & $\begin{array}{c}\mathrm{D} \\
(3)\end{array}$ \\
\hline Windows and doors every 100m & $\mathrm{A}$ & $\mathrm{A}$ & $\mathrm{A}$ & $\mathrm{A}$ \\
& $(28)$ & $(18)$ & $(25)$ & $(31)$ \\
\hline Range of functions & $\mathrm{B}$ & $\mathrm{C}$ & $\mathrm{C}$ & $\mathrm{C}$ \\
\hline Blind or passive facade & $\mathrm{A}$ & $\mathrm{A}$ & $\mathrm{A}$ & $\mathrm{A}$ \\
\hline Depth and relief in the building surface & $\mathrm{B}$ & $\mathrm{B}$ & $\mathrm{B}$ & $\mathrm{B}$ \\
\hline Quality of materials and details & $\mathrm{C}$ & $\mathrm{C}$ & $\mathrm{C}$ & $\mathrm{C}$ \\
\hline
\end{tabular}

Table 5. Osiedle Centrum C characteristics

\begin{tabular}{|l|l|}
\hline \multicolumn{2}{|l|}{ Osiedle Centrum C urban block } \\
\hline Urban block area & $34940 \mathrm{~m} 2$ \\
\hline Total overground floors area & $64576 \mathrm{~m} 2$ \\
\hline Built up area & $11140 \mathrm{~m} 2$ \\
\hline Density (net) & 1,85 \\
\hline Average floor ratio & 5,8 \\
\hline
\end{tabular}

It is suggested that, given the low car ownership at the time of its inception, an important function of the Neo Baroque configuration of wide streets was to provide ample space for the carefully orchestrated demonstrations and processions organised by the communist regime. It also may be that the wide streets could also facilitate the suppression of any demonstrations against the regime - like the Parisian 19th Century boulevards.

Further research is needed to ascertain the origins of the ideas which informed the design of Nowa Huta but some preliminary reflections suggest that there were contemporary models which demonstrate the same street layout if not with the same motivation. Post World War II Le Havre as rebuilt by Perret (Hatherley, 2016 ) and even parts of pre war Welwyn Garden City are characterised by wide straight streets and long vistas.

Apartment buildings with no entrances on the street elevation can be found on other socialist developments (Lorek, 1992) like Magnitogorsk, Novi Beograd even though the street networks follow a very different configuration to that of Nowa Huta. An earlier model which bears a striking similarity to Nowa Huta are the interwar Viennese Hofe such as the George Washington- Hof or the Karl Volkert-Hof (Tafuri, 1980).

The paper concludes with a comment on the extent to which very different political economies can produce similar forms. Pancewicz (2015) has discussed in general terms the relevance of New Urbanism to the contemporary Polish context but does a geometry which tries to meet human needs have a more general application beyond the imperatives of politics and economics? If this can be demonstrated then it is a powerful argument for the autonomy of urban form.

This conflict between the street and the urban block in the facilitation of pedestrian movement gives rise to this hypothesis. There are in fact some New Urbanism schemes where street activity is reduced by the possibility of increased connections within the urban blocks, like Poundbury (Dorchester, Dorset, UK) or Vista Field (Kennewick, Washington, USA).

\section{References}

Bittner J. (ed) (1971) Miastoprojekt Kraków 1951-1971, Wyd. Artystyczno-Graficzne, Kraków.

Congress for the New Urbanism (1999) Charter of the New Urbanism (1999). (https://www. cnu.org/who-we-are/charter-new-urbanism) accessed 4 January 2017

Decyzja w sprawie wpisania zabytku do rejestru zabytków nieruchomych http:// www.bip.krakow.pl/?sub_dok_id=514 accessed 26 May 2017 
https://en.wikipedia.org/wiki/Poundbury accessed 27 May 2017

http://www.nh.pl/ludzie_ptaszycki.htm accessed 27 May 2017

http://www.dpz.com/Projects/1408 accessed 27 May 2017

Gauthier P. and Gilliland J. (2006), 'Mapping urban morphology: a classification scheme for interpreting contributions to the study of urban form', Urban Morphology 10.1, p 4150

Gehl J. (1994) Places for People: Melbourne city 1994, City of Melbourne Urban Design Branch and Strategic Planning Branch in cooperation with Jan Gehl, City of Melbourne, Melbourne.

Hatherley O. (2015) Landscapes of Communism. A history through buildings, Allen Lane,London.

Hatherley O. (2016) Eurovisionaries https:// www.architectsjournal.co.uk/culture/ owen-hatherleys-eurovisionaries-lehavre/10006268.article accessed 4 March 2017.

Hirt S., Stanilow K. (2009) Twenty years of transition: the evolution of urban planning in Eastern Europe and the former Soviet Union, 1989-2009, Human Settlements Global Dialogue Series, No 5, UN HABITAT.

Hudson, H.D. (1994) Blueprints and Blood: the Stalinization of Soviet architecture , 1917-1937, Princeton University Press, Chichester .

Jeleński T. (2015) Tradition and heritage in the image of Krakow, ed Jeleński et al [in:] Tradition and heritage in the contemporary image of the city Krakow volume 1, Politechnika Krakowska, Krakow, p 95-12.

Juchnowicz S. (1986) Nowa Huta, Architektura, 1986/1 p 67-72.

Juchnowicz, S. (2005) 'Nowa Huta, przeszłość i wizja - $z$ doświadczeń warsztatu projektowego' [in:] Salwiński J., Sibila L. J. eds. Nowa Huta, przeszłość i wizja. Studium muzeum rozproszonego, Biblioteka Krzysztoforska, Muzeum Historyczne m. Krakowa, Krakow, p 177-230

Kliems, A., Dmitrieva, M. eds. (2010) The post-socialist city. Continuity and change in urban space and imagery, Jovis, Berlin.

Komorowski W. (2005) 'Wartości kulturowe
Nowej Huty. Urbanistyka i architektura' [in:] Salwiński J., Sibila L. J. eds. Nowa Huta, przeszłość i wizja. Studium muzeum rozproszonego, Biblioteka Krzysztoforska, Muzeum Historyczne m. Krakowa, Krakow, p 97-142.

Lebow, K. (2013) Unfinished Utopia; Nowa Huta, Stalinism and Polish society, 1949-56, Cornell University Press.

Lisowski, B. (1968) Modern architecture in Poland, Polonia Publishing House, Warsaw.

Lorek A. (1992) Geneza powstania i rozwoju realizmu socjalistycznego $\mathrm{w}$ architekturze i urbanistyce na tle przemian społecznopolitycznych w Europie w latach 1917-55 : PhD Thesis, CUT.

Lorek A. (1999) 'Kompozycja przestrzenna Nowej Huty w kontekście teorii i praktyki urbanistycznej socrealizmu' [in:] Małecki J. ed. Narodziny Nowej Huty, Krakow, p 121136

Maretto, M. (2012) Saverio Muratori il projectto della citta, Franco Angeli, Milan.

Miezian M., Sibila L. J., Lorek A., Juchnowicz S. (2006) Nowa Huta - architektura i twórcy miasta idealnego, Muzeum Historyczne miasta Krakowa, Krakow.

http://www.newurbanism.org/newurbanism/ principles.html accessed 27 May 2017

Pancewicz L. (2015) Can grand design doctrines go well with locally reinvented urbanisms? Notes from Polish cities in transition, [in:] Jeleński et al eds. Tradition and heritage in the contemporary image of the city Politechnika Krakowska, Krakow volume 1, p. 132-153

Panerai Ph., Castex J., Samuels I. (2004), Urban Forms. The Death and Life of the Urban Block, Architectural Press, Oxford.

Plater-Zyberk E. (2015) 'Traditional urbanism: design policy and case studies' [in:] Jeleński et al eds. Tradition and heritage in the contemporary image of the city, Volume 1, Politechnika Krakowska, Krakow p. 160171.

Ptaszycki T. (1953). Nowa Huta, Architektura, 1953/3, p 62-74.

Smaga M. (2017) Nowa Huta - założenie urbanistyczne

http://szlakmodernizmu.pl/szlak/bazaobiektow/nowa-huta-\%E2\%80\%93- 
zalozenie-urbanistyczne accessed 26 May 2017.

Stanilov K. ed. (2007) The Post Socialist City, Springer, Dordrecht.

Stenning A. (2000) Placing (Post-) Socialism; the making and remaking of Nowa Huta, Poland, European Urban and Regional Studies 7 (2) p 99-118.

Tafuri M. ed. (1980) Vienna Rossa. La politica residentiale nella Vienna socialista, Electa, Milan.

Urbaniec J. (2014) W Nowej Hucie miał stać Pałac Kultury, wywiad z S. Juchnowiczem 10 lipca $2014 \mathrm{http}: / /$ www.gazetakrakowska. pl/artykul/3502455,w-nowej-hucie-mialstac-palac-kultury-archiwalne-zdjecia,id,t. html accessed 26 May 2017.

IX International Biennale of Architecture (2002) Information Materials, SARP, Krakow. 